\title{
KETERKAITAN ANTARA KARAKTERISTIK KONSUMEN DENGAN TINGKAT KEPUASAN MEREKA DALAM MELAKUKAN PEMBELIAN SAYURAN ORGANIK DI PASAR MODERN KOTA MEDAN
}

\author{
Elly Rasmikayati ${ }^{1}$, Nurisa Asrienda Shafira ${ }^{1}$, Yuniar Dianti Fauziah ${ }^{1}$, Hanifatur \\ Aziz Nur Ishmah ${ }^{1}$, Bobby Rachmat Saefudin ${ }^{2}$, Khairuna Utami ${ }^{3}$ \\ ${ }^{1}$ Fakultas Pertanian, Universitas Padjadjaran, Jl. Bandung-Sumedang KM. 21, Jatinangor, \\ 45363. Email: e.rasmikayati@unpad.ac.id \\ ${ }^{2}$ Fakultas Pertanian, Ma'soem University, Jl. Raya Cipacing No.22, Jatinangor, 45363 \\ ${ }^{3}$ Fakultas Pertanian, Universitas Sumatera Utara, Jalan Dr. T. Mansur No.9, Padang \\ Bulan, Kec. Medan Baru, Kota Medan, 20222
}

\begin{abstract}
Abstrak
Kesadaran konsumen akan pentingnya menjaga kesehatan dari sisi mengkonsumsi sayuran organik semakin meningkat dan banyak faktor yang berperan dalam menentukan tingkat pembeliannya. Penelitian ini bertujuan untuk mengetahui deskripsi dari karakteristik konsumen dan hubungannya terhadap tingkat kepuasan dalam melakukan pembelian sayuran organik di pasar modern Kota Medan. Desain penelitian ini dilakukan dengan pendekatan metode deskriptif kuantitatif menggunakan sampel berukuran 90 responden. Metode analisis yang digunakan untuk analisis karakteristik konsumen adalah statistik deskriptif dan analisis hubungan antara karakteristik dengan tingkat kepuasan adalah crosstab dan uji chi-square. Hasil penelitian menunjukan bahwa deskripsi karakteristik konsumen berdasarkan jenis kelamin didominasi oleh perempuan, berusia 31 sampai 40 tahun, berpendapatan antara 2.000.001 sampai 3.000.000 rupiah, lamanya menempuh pendidikan 16 tahun atau setara dengan S1 dan memiliki jumlah tanggungan keluarga sebanyak 2 orang. Sementara itu, hasil analisis menunjukkan bahwa terjadi hubungan yang signifikan antara pada variabel lamanya menempuh pendidikan dengan tingkat kepuasan konsumen dalam melakukan pembelian sayuran organik di Kota Medan. Sedangkan untuk variabel-variabel karakteristik lainnya tidak terjadi hubungan yang signifikan dengan tingkat kepuasan.
\end{abstract}

Kata kunci: Karakteristik, kepuasan konsumen, sayuran organik, crosstab, chi-square

\section{Abstract}

Consumer awareness of the importance of maintaining health in terms of consuming organic vegetables is increasing and many factors play a role in determining the level of purchase. This study aims to determine the description of consumer characteristics and their relationship to the level of satisfaction in purchasing organic vegetables in the city of Medan. The design of this study was conducted with a quantitative descriptive method approach using a sample of 90 respondents. The analytical method used for the analysis of consumer characteristics is descriptive statistics and the analysis of the relationship between characteristics and the level of satisfaction is the crosstab and chi-square test. The results showed that the description of consumer characteristics based on gender was dominated by women, aged 31 to 40 years, earning between 2,000,001 to 3,000,000 rupiah, length of education 16 years or equivalent to S1 and having a total family of 2 people. Meanwhile, the results of the analysis show that there is a significant relationship between the length of education variables and the level of consumer satisfaction in purchasing organic vegetables in the city of Medan. Whereas for the other characteristic variables there was no significant relationship with satisfaction level.

Keywords: Characteristics, customer satisfaction, organic vegetables, crosstab, chi-square 


\section{Pendahuluan}

Terjadinya pergeseran pola hidup masyarakat ke arah yang lebih mementingkan lingkungan dan kebutuhan kesehatan tubuh yang mampu menghadirkan dan meningkatkan minat masyarakat akan produk organik (Rasmikayati dkk., 2020). Masyarakat kian menyadari hal-hal berkenaan dengan dampak buruk dari bahan kimia terhadap kesehatan yang mungkin digunakan pada proses produksi produk pertanian. Suleman dkk. (2006) menyampaikan bahwa telah dilakukan regulasi perdagangan global yang memerhatikan hal-hal terkait produk pertanian seperti atribut aman konsumsi (food safety attributes), kandungan nutrisi tinggi (nutritional attributes), serta ramah lingkungan (eco-labelling attributes) sebagai pengadaan pelembagaan internasional terhadap perubahan gaya hidup yang memerhatikan lingkungan.

Utami dan Chaeriyah (2019) mengartikan sayuran organik sebagai sayuran yang diusahakan dengan pelaksanaan praktik budidaya tanaman dengan menggunakan bahan organik, teknik pergiliran tanaman yang tepat, dan terbebas dari pengaplikasian pupuk dan pestisida sintetis. Sayur organik merupakan salah satu komoditas produk pertanian organik yang banyak dikembangkan (Pardian, 2017). Hal tersebut disebabkan oleh mudahnya proses budidaya komoditas sayuran yang dilangsungkan tanpa pemberian bahan kimia. Selain itu, kandungan yang terdapat pada tanaman sayuran pun baik untuk kesehatan tubuh. Menurut data yang dilampirkan oleh BPS, terjadi peningkatan terhadap komsumsi sayur organik secara nasional pada tahun 2015-2016. Merujuk pada Rasmikayati dkk. (2020), faktor-faktor yang dapat memengaruhi tingkat kepuasan konsumen sayuran organik yaitu kualitas produk dan kualitas pelayanan. Hal-hal yang diperhatikan konsumen terkait kualitas produk sayuran organik antara lain yaitu cacat fisik oleh serangga, kemasan produk, dan harga yang sesuai dengan kualitas produk. Sedangkan hal-hal yang diperhatikan konsumen terkait kualitas pelayanan yaitu kesabaran karyawan saat melayani konsumen, penjelasan dari keluh kesah yang dipaparkan konsumen, kecepatan dan kesiapan karyawan dalam melayani konsumen, serta pengetahuan karyawan terkait sayuran organik.

Menurut berbagai penelitian terkait pola pembelian konsumen (Sari dkk., 2020; Saefudin dkk., 2020; Natawidjaja dkk., 2017; dan Rasmkayati dkk., 2017), terdapat beberapa karakteristik individu yang mungkin memengaruhi keputusan konsumen terhadap pembelian produk sayuran organik, antara lain yaitu usia, jumlah pendapatan, jumlah tanggungan keluarga, dan pendidikan. Penelitian yang dilakukan Shanmudapriya dkk. (2014) di Tamil, India, menunjukkan bahwa variabel usia, pendidikan, dan pendapatan berpengaruh terhadap keputusan pembelian sayuran organik dengan $60 \%$ responden berusia lebih dari 45 tahun, $60 \%$ responden telah lulus dari perguruan tinggi, dan $75 \%$ responden berpendapatan sebesar Rs. 30,000. Responden yang tergolong cukup tua lebih sadar atas kebutuhan menjalani pola hidup sehat oleh tingginya risiko kesehatan yang mereka miliki. Sedangkan respon dengan yang telah lulus dari perguruan tinggi lebih paham mengenai pola hidup sehat oleh ilmu yang telah diperolah. Adapun pendapatan yang tinggi memperbolehkan konsumen untuk membeli produk organik yang berharga tinggi. Meskipun begitu, penelitian oleh Devi dan Hartono (2015) di Salatiga menyatakan bahwa usia dan jumlah tanggungan keluarga tidak berpengaruh terhadap keputusan pembelian sayuran organik. Hal tersebut disebabkan oleh setiap konsumen memiliki kesadaran atas pentingnya mengonsumsi sayuran yang menjadikan setiap konsumen untuk selalu melakukan pembelian sayuran.

Engel et al. (1993) menyatakan bahwa konsumen tidak hanya melakukan pembelian produk, tetapi juga melakukan evaluasi pasca pembelian akibat kepuasan 
atau ketidakpuasan atas produk terkait. Kepuasan yang dirasakan konsumen akan berdampak baik pada keyakinan dan sikap konsumen terhadap pembelian selanjutnya. Sedangkan ketidakpuasan yang dirasakan konsumen akan berdampak buruk pada keyakinan dan sikap konsumen. Maka dari itu, produsen perlu melakukan berbagai upaya untuk mempertahankan pelanggan dengan pemberian perasaan puas. Salah satu variabel yang perlu diperhatikan oleh produsen dalam mempertahankan pelanggan yaitu kualitas dan harga.

Dalam rangka menelaah hal-hal terkait kepuasan konsumen, perlu dilakukan penelitian mengenai hubungan karakteristik konsumen terhadap kepuasan dalam pembelian sayuran organik di Kota Medan.

\section{Metode Penelitian}

Objek penelitian ini adalah karakteristik dan tingkat kepuasan konsumen sayuran organik. Penelitian ini dilakukan di pasar modern di Kota Medan yaitu Lotte Mart, Transmart Carefour, dan Maju Bersama Pulo Brayan dengan pertimbangan dan sayur organik yang tersedia lebih lengkap dan lebih banyak untuk dijadikan objek penelitian. Rancangan penelitian ini dilakukan dengan pendekatan metode deskriptif kuantitatif menggunakan sampel berukuran 90 responden yang ditentukan menggunakan teknik systematic random sampling dengan interval 3 kedatangan.

Variabel-variabel penelitian untuk karakteristik konsumen diantaranya: jenis kelamin, usia, pendapatan, lamanya pendidikan dan jumlah tanggungan keluarga. Sedangkan variabel-variabel penelitian untuk kepuasan konsumen diantaranya: kepuasan konsumen setelah mengkonsumsi sayur organik, persepsi konsumen mengenai harga sayur organik dan reaksi konsumen ketika harga sayur organik yang biasa dikonsumsinya mengalami kenaikan.

Analisis karakteristik konsumen menggunakan analisis deskripsi dimana menggambarkan tentang ciri dari seseorang yang dapat mempengaruhi proses pembelian yaitu diantaranya: jenis kelamin, usia, tingkat pendapatan, tingkat pendidikan dan jumlah anggota keluarga yang ditanggung. Analisis deskripsi menggunakan diagram pie, diagram batang, dan diagram box plot menggambarkan keragaman data, penyebaran data, pemusatan data, dan juga melihat outlier dari tiap-tiap variabel yang diteliti (Junaidi, 2014).

Analisis hubungan antara karakteristik konsumen dengan tingkat kepuasan menggunakan analisis crosstab dimana untuk menghitung frekuensi dan presentasi 2 atau lebih variabel yang mudah dipahami secara deskriptif. Sedangkan uji chi-square digunakan untuk mengetahui hubungan antara karakteristik konsumen dengan tingkat kepuasan konsumen dalam melakukan pembelian sayuran organik di Kota Medan. Analisis Chi-Square diperoleh dari uji chi-square yang berfungsi untuk menyusun variabel-variabel yang diuji dengan tabel dan menguji apakah terdapat hubungan antara variabel-variabel tersebut (Junaidi, 2010).

- Ho: Tidak terdapat hubungan yang signifikan antara karakteristik konsumen dengan kepuasan konsumen membeli sayuran organik di Kota Medan.

- Ha: Terdapat hubungan yang signifikan antara karakteristik konsumen dengan kepuasan konsumen membeli sayuran organik di Kota Medan.

- Taraf nyata $(\alpha): 5 \%=0,05$

\section{Hasil dan Pembahasan}

\section{Karakteristik Konsumen}

Responden dalam penelitian ini adalah konsumen sayur organik yang berjumlah 90 jiwa. Karakteristik yang dimaksud dalam penelitian ini adalah jenis kelamin, usiar, tingkat pendidikan, tingkat pendapatan konsumen dan jumlah anggota keluarga 
yang ditanggung.

\subsection{Jenis Kelamin}

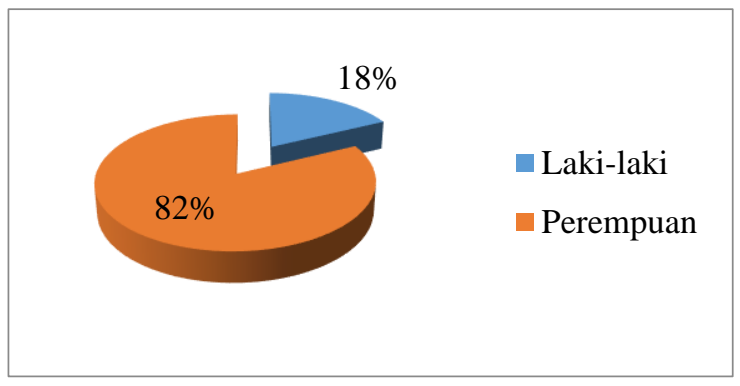

Sumber: Pengolahan data (2020)

\section{Gambar 1}

\section{Diagram Jenis Kelamin Konsumen} Sayuran Organik di Kota Medan

Berdasarkan Gabar 1 dapat dilihat bahwa responden di Kota Medan didominasi oleh jenis kelamin perempuan dengan presentase $82 \%$. Kemudian data yang sering muncul adalah perempuan. Berdasarkan penelitian Mersilia (2015), sebagian besar konsumen sayuran organik di Hypermart manado juga berjenis kelamin perempuan dengan presentase 73\%. Pada studi kasus Ujenk Mart Bandung juga memiliki mayoritas responden perempuan dengan presentase 71\% (Utami dan Chaeriyah, 2019). Hal ini didukung karena seringkali terlihat di pasar maupun ritel modern yang berbelanja untuk membeli sayuran organik atau kebutuhan rumah tangga adalah perempuan sedangkan laki-laki bekerja untuk mencari nafkah.

\subsection{Usia}

Berdasarkan Gambar 2 dapat dilihat bahwa responden di Kota Medan didominasi yang berusia antara 31 sampai 40 tahun dengan presentase $42 \%$. Kemudian data yang sering muncul dalam mengonsumsi sayur organik adalah responden dengan usia 35,5 tahun.

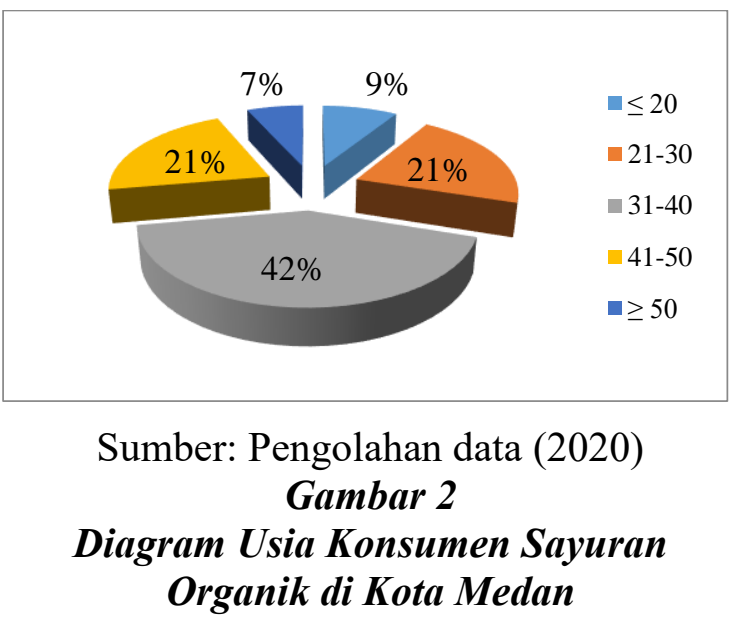

Berdasarkan penelitian Tangkulung dkk. (2015), sebagian besar konsumen sayuran organik di Hypermart manado berusia sekitar 21 sampai 30 tahun yaitu sebanyak 23 orang dengan presentase $56 \%$. Sedangkan, pada studi kasus Ujenk Mart Bandung memiliki mayoritas responden berusia sekitr 26 sampai 35 tahun dengan presentase $43 \%$ (Utami dan Chaeriyah, 2019). Hal ini dapat didukung pada usia produktif biasanya sudah mulai memperhatikan kesehatannya dan yang sudah dewasa akan lebih memperhatikan kesehatannya. Menurut analisis diagram box plot pada karakteristik usia didapatkan hasil sebagai berikut:

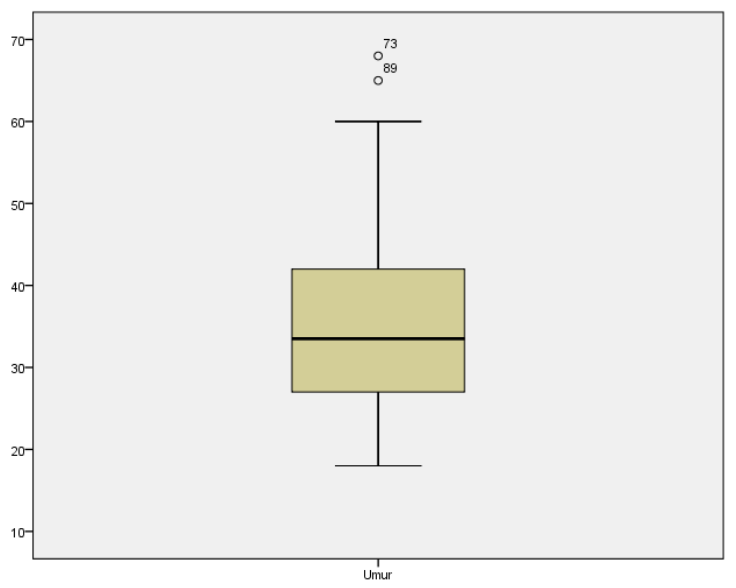

Sumber: Pengolahan data (2020)

Gambar 3

Box Plot Usia Konsumen Sayuran Organik di Kota Medan 
Dilihat dari Gambar 3, bentuk kotak tidak terlalu panjang menunjukkan bahwa keragaman usia responden tidak terlalu bervariasi. Kemudian dapat diketahui bahwa data usia responden tidak simetris karena median tidak berada di tengah dan salah satu garis whisker lebih panjang dari yang lainnya. Maka, dapat diartikan bahwa data memusat di sebelah bawah atau usia responden lebih cenderung muda. Berdasarkan Gambar 3, terdapat nilai yang berada di atas garis whisker yang berarti terdapat nilai ekstrim dari data usia responden yaitu responden yang berusia di atas 60 tahun.

1.3 Pendapatan

Tabel 1

Karakteristik Konsumen Berdasarkan Pendapatan

\begin{tabular}{clc}
\hline No. & \multicolumn{1}{c}{ Range Pendapatan } & $\begin{array}{c}\text { Jumlah } \\
\text { (Orang) }\end{array}$ \\
\hline 1 & $0-1.000 .000$ & 6 \\
2 & $1.000 .001-2.000 .000$ & 9 \\
3 & $2.000 .001-3.000 .000$ & 41 \\
4 & $3.000 .001-4.000 .000$ & 22 \\
5 & $4.000 .001-5.000 .000$ & 8 \\
6 & $5.000 .001-6.000 .000$ & 1 \\
7 & $6.000 .001-7.000 .000$ & 1 \\
8 & $7.000 .001-8.000 .000$ & 1 \\
9 & $8.000 .001-9.000 .000$ & 1 \\
10 & $9.000 .001-10.000 .000$ & 1 \\
\hline
\end{tabular}

Sumber: Pengolahan data (2020)

Berdasarkan Tabel 1 dapat dilihat bahwa responden di Kota Medan didominasi yang memiliki pendapatan $\mathrm{Rp} 2.000 .001$ 3.000 .000 dengan presentase $45 \%$. Kemudian data yang sering muncul adalah tingkat pendapatan sebesar 2.666.666 rupiah. Berdasarkan studi kasus pada Ujenk Mart Bandung, mayoritas responden berpenghasilan rata-rata $\mathrm{Rp} 4.000 .000-$ 6.999 .999 dengan presentase 32\% (Utami dan Chaeriyah, 2019). Perbedaan pendapatan dalam membeli sayuran organik ini tidak menjadi masalah karena hal ini dapat didukung dengan pernyataan bahwa responden mampu membeli sayuran organik yang harganya lebih mahal dari sayur anorganik karena tidak rutin setiap hari dalam membelinya. Menurut analisis diagram box plot pada karakteristik pendapatan didapatkan hasil sebagai berikut:

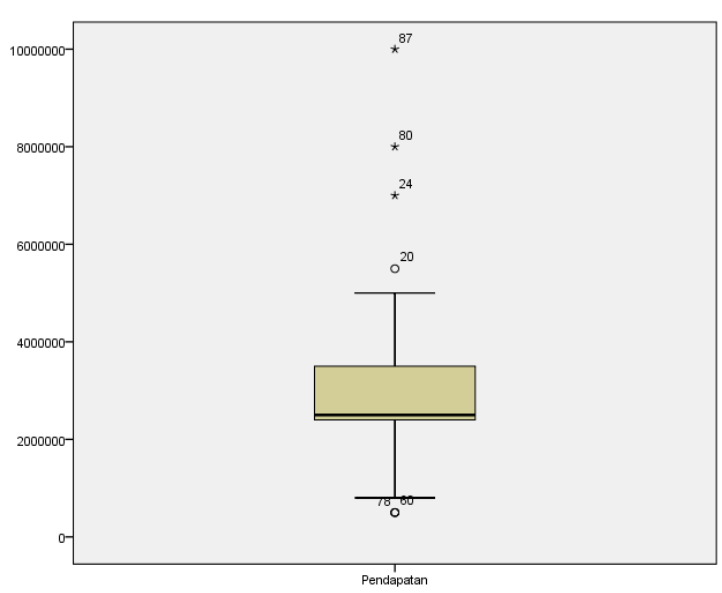

Sumber: Pengolahan data (2020)

Gambar 4

\section{Box Plot Pendapatan Konsumen Sayuran Organik di Kota Medan}

Dilihat dari Gambar 4, bentuk kotak tidak terlalu panjang menunjukkan bahwa keragaman pendapatan responden tidak terlalu bervariasi. Kemudian dapat diketahui bahwa data pendapatan responden tidak simetris karena median tidak berada di tengah dan salah satu garis whisker lebih panjang dari yang lainnya. Maka, dapat diartikan bahwa data memusat di sebelah bawah atau pendapatan responden lebih cenderung rendah. Selain itu juga terdapat nilai yang berada di atas dan di bawah garis whisker yang berarti terdapat nilai ekstrim dari data pendapatan responden.

\subsection{Pendidikan}

Dari Tabel 2 dapat dilihat bahwa responden di Kota Medan didominasi oleh yang pendidikannya berlangsung selama 16 tahun yang setara S1 atau D4 dengan presentase $69 \%$. Berdasarkan studi kasus pada Hypermart Manado, mayoritas responden berada pada tingkat pendidikan S1 yaitu 
terdapat 28 orang dengan persentase $70 \%$ (Tangkulung dkk., 2015). Hal ini dapat didukung dengan pernyataan bahwa seorang konsumen dengan tingkat pendidikan yang tinggi cenderung lebih memilih produk makanan yang berkualitas atau lebih baik untuk kesehatan karena lebih memahami tentang gizi dan hubungannya dengan kesehatan.

\section{Tabel 2}

\section{Karakteristik Konsumen Berdasarkan} Pendidikan

\begin{tabular}{clc}
\hline No. & Pendidikan & $\begin{array}{c}\text { Jumlah } \\
\text { (Orang) }\end{array}$ \\
\hline 1 & SMP & 1 \\
2 & SMA & 6 \\
3 & D3 & 12 \\
4 & D4/S1 & 62 \\
5 & S2 & 7 \\
6 & S3 & 2 \\
\hline
\end{tabular}

Sumber: Pengolahan data (2020)

Sedangkan menurut analisis diagram box plot pada karakteristik pendidikan didapatkan hasil sebagai berikut:

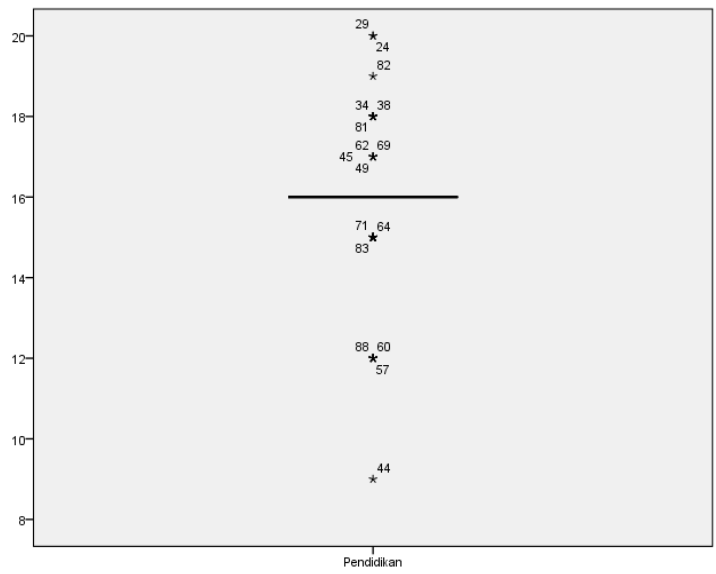

Sumber: Pengolahan data (2020)

\section{Gambar 5}

\section{Box Plot Pendidikan Konsumen Sayuran Organik di Kota Medan}

Berdasarkan Gambar 5, gambar tidak menyerupai kotak yaitu hanya menyerupai garis lurus menunjukkan bahwa keragaman lamanya pendidikan yang ditempuh responden tidak bervariasi. Kemudian dapat diketahui bahwa data lamanya pendidikan yang ditempuh responden simetris karena median berada satu garis lurus dengan Q1 dan Q3. Maka, dapat diartikan bahwa data memusat pada data lamanya pendidikan yang ditempuh responden yaitu 16 tahun. Dan terdapat nilai yang berada di atas dan di bawah garis whisker yang berarti terdapat nilai ekstrim dari data lamanya pendidikan yang ditempuh responden.

\subsection{Jumlah Anggota Keluarga yang Ditanggung}

Berdasarakan Gambar 6, dapat dilihat bahwa responden di Kota Medan didominasi oleh responden yang memiliki jumlah anggota keluarga yang ditanggungnya sebanyak 2 orang dengan presentase $29 \%$. Berdasarkan studi kasus di Kota Medan, mayoritas responden memliki tanggungan anggota keluarga sebanyak 2 orang dengan persentase 29\% (Utami dkk., 2019). Hal ini dapat didukung dengan pernyataan bahwa konsumen yang memiliki jumlah keluarga tidak lebih dari 4 orang cenderung lebih mampu untuk membeli sayuran organik karena tanggungan anggota keluarga yang tidak terlalu banyak.

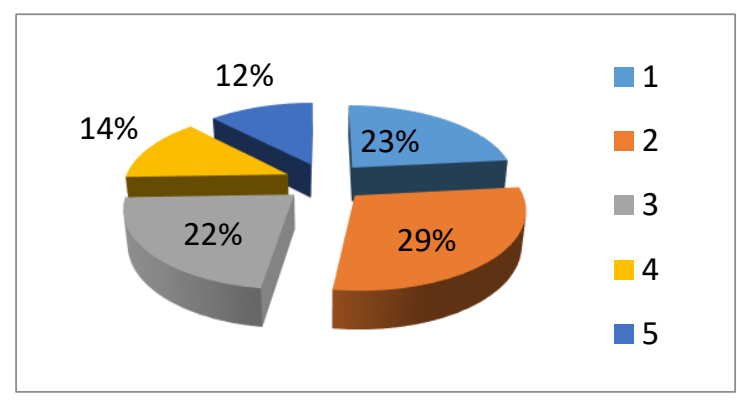

Sumber: Pengolahan data (2020)

\section{Gambar 6}

Diagram Jumlah Anggota Keluarga yang Ditanggung Konsumen Sayuran Organik di Kota Medan

Sedangkan menurut analisis diagram box plot pada karakteristik jumlah anggota keluarga yang ditanggung didapatkan hasil sebagai berikut: 


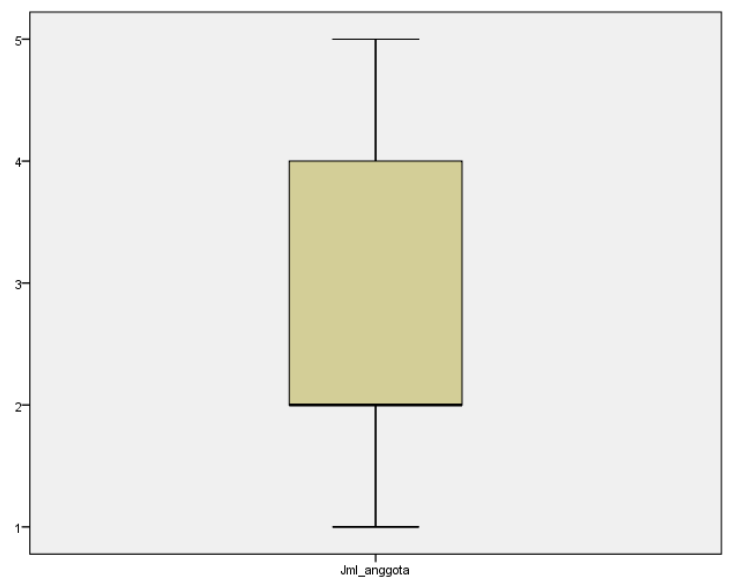

Sumber: Pengolahan data (2020)

Gambar 7

Box Plot Jumlah Anggota Keluarga yang Ditanggung Konsumen Sayuran Organik di Kota Medan

Dilihat dari Gambar 7, bentuk kotak tidak terlalu panjang menunjukkan bahwa keragaman jumlah anggota yang ditanggung responden tidak terlalu bervariasi. Kemudian dapat diketahui bahwa data jumlah anggota keluarga yang ditanggung responden tidak simetris karena median tidak berada di tengah dan salah satu garis whisker lebih panjang dari yang lainnya. Maka, dapat diartikan bahwa data memusat di sebelah bawah atau jumlah anggota keluarga yang ditanggung responden lebih cenderung sedikit. Dan tidak terdapat nilai yang berada di atas maupun di bawah garis whisker yang berarti tidak terdapat nilai ekstrim dari data jumlah anggota keluarga yang ditanggung responden.

\section{Kepuasan Konsumen}

Berdasarkan Gambar 8, dapat dilihat bahwa responden di Kota Medan setelah membeli dan mengonsumsi sayur organik didominasi oleh yang memilih tingkat kepuasan yang puas dengan presentase 59\%. Berdasarkan studi kasus di Super Indo Yogyakarta, secara keseluruhan responden menyatakan puas terhadap sayuran organik dengan skor ratarata tingkat kepuasan konsumen sebesar 3,79 (Purwati, 2017). Kepuasan konsumen yang cukup tinggi ini didukung oleh manfaat yang didapatkan konsumen setelah membeli sayuran organik. Selain itu, hal ini juga menunjukkan bahwa sayuran organik yang dijual dapat diterima dengan baik oleh konsumen.

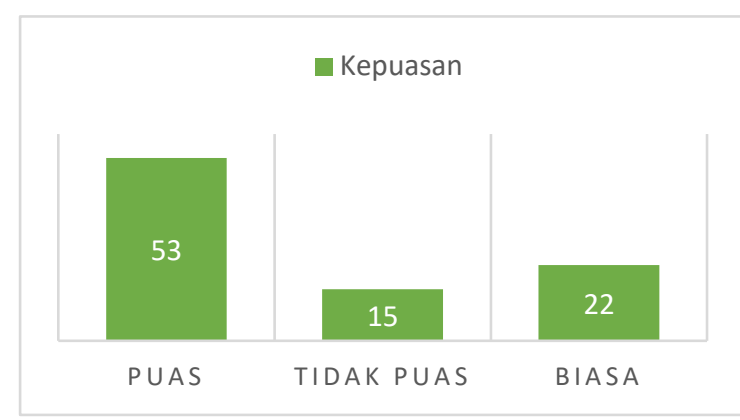

Sumber: Pengolahan data (2020)

Gambar 8

Diagram Kepuasan Konsumen Sayuran Organik di Kota Medan

\section{Hubungan Karakteristik Konsumen Dengan Tingkat Kepuasan}

\subsection{Hubungan Jenis Kelamin Dengan} Tingkat Kepuasan

\section{Tabel 3}

Tabulasi Silang Jenis Kelamin dengan Tingkat Kepuasan

\begin{tabular}{|c|c|c|c|c|c|}
\hline \multirow{2}{*}{\multicolumn{2}{|c|}{$\begin{array}{l}\text { Frekuensi } \\
\text { Responden }\end{array}$}} & \multicolumn{3}{|c|}{ Tingkat Kepuasan } & \multirow[b]{2}{*}{ Total } \\
\hline & & $\begin{array}{l}\text { Tidak } \\
\text { Puas }\end{array}$ & Cukup & Puas & \\
\hline \multirow{4}{*}{$\begin{array}{c}\text { Jenis } \\
\text { Kela- } \\
\text { min }\end{array}$} & Laki- & 2 & 4 & 10 & 16 \\
\hline & laki & $(2 \%)$ & $(5 \%)$ & $(11 \%)$ & $(18 \%)$ \\
\hline & Perem & 7 & 19 & 48 & 74 \\
\hline & puan & $(8 \%)$ & $(21 \%)$ & $(53 \%)$ & $(82 \%)$ \\
\hline \multirow{2}{*}{\multicolumn{2}{|c|}{ Total }} & 9 & 23 & 58 & 90 \\
\hline & & $(10 \%)$ & $(26 \%)$ & $(64 \%)$ & $(100 \%)$ \\
\hline
\end{tabular}

Sumber: Pengolahan data (2020)

Berdasarkan Tabel 3 dapat diketahui bahwa terdapat 10 responden laki-laki yang merasa puas membeli sayuran organik (11\%) dan 48 responden perempuan yang merasa puas membeli sayuran organik (53\%). Berdasarkan hasil uji chi-square dapat diperoleh nilai probabilitas $0,935>0,05$ 
maka dapat disimpulkan bahwa Ho diterima yang artinya tidak terdapat hubungan yang signifikan antara jenis kelamin responden dengan kepuasan konsumen membeli sayuran organik di Kota Medan.

\subsection{Hubungan Usia Dengan Tingkat Kepuasan}

\section{Tabel 4}

Tabulasi Silang Usia dengan Tingkat Kepuasan

\begin{tabular}{|c|c|c|c|c|c|}
\hline \multirow{2}{*}{\multicolumn{2}{|c|}{$\begin{array}{l}\text { Frekuensi } \\
\text { Responden }\end{array}$}} & \multicolumn{3}{|c|}{ Tingkat Kepuasan } & \multirow[b]{2}{*}{ Total } \\
\hline & & $\begin{array}{l}\text { Tidak } \\
\text { Puas }\end{array}$ & Cukup & Puas & \\
\hline \multirow{6}{*}{$\begin{array}{c}\text { Usia } \\
\text { (Tah- } \\
\text { un) }\end{array}$} & $10-20$ & $\begin{array}{c}1 \\
(1 \%)\end{array}$ & $\begin{array}{c}2 \\
(2 \%)\end{array}$ & $\begin{array}{c}5 \\
(6 \%)\end{array}$ & $\begin{array}{c}8 \\
(9 \%)\end{array}$ \\
\hline & $21-30$ & $\begin{array}{c}2 \\
(2 \%)\end{array}$ & $\begin{array}{c}5 \\
(6 \%)\end{array}$ & $\begin{array}{c}12 \\
(13 \%)\end{array}$ & $\begin{array}{c}19 \\
(21 \%)\end{array}$ \\
\hline & $31-40$ & $\begin{array}{c}2 \\
(2 \%)\end{array}$ & $\begin{array}{c}11 \\
(12 \%)\end{array}$ & $\begin{array}{c}25 \\
(28 \%)\end{array}$ & $\begin{array}{c}38 \\
(42 \%)\end{array}$ \\
\hline & $41-50$ & $\begin{array}{c}3 \\
(4 \%)\end{array}$ & $\begin{array}{c}4 \\
(5 \%)\end{array}$ & $\begin{array}{c}12 \\
(13 \%)\end{array}$ & $\begin{array}{c}19 \\
(21 \%)\end{array}$ \\
\hline & $51-60$ & $\begin{array}{c}1 \\
(1 \%)\end{array}$ & $\begin{array}{c}1 \\
(1 \%)\end{array}$ & $\begin{array}{c}2 \\
(2 \%)\end{array}$ & $\begin{array}{c}4 \\
(5 \%)\end{array}$ \\
\hline & $61-70$ & $\begin{array}{c}0 \\
(0 \%)\end{array}$ & $\begin{array}{c}0 \\
(0 \%)\end{array}$ & $\begin{array}{c}2 \\
(2 \%)\end{array}$ & $\begin{array}{c}2 \\
(2 \%)\end{array}$ \\
\hline \multicolumn{2}{|c|}{ Total } & $\begin{array}{c}9 \\
(10 \%)\end{array}$ & $\begin{array}{c}23 \\
(26 \%)\end{array}$ & $\begin{array}{c}58 \\
(64 \%)\end{array}$ & $\begin{array}{c}90 \\
(100 \%)\end{array}$ \\
\hline
\end{tabular}

Sumber: Pengolahan data (2020)

Berdasarkan Tabel 4 dapat diketahui bahwa untuk responden dengan rentang usia 31 40 tahun paling banyak yang merasa puas membeli sayuran organik dengan jumlah 25 responden (28\%). Berdasarkan hasil uji chisquare diperoleh nilai probabilitas $0,946>$ 0,05 maka dapat disimpulkan bahwa Ho diterima yang artinya tidak terdapat hubungan yang signifikan antara usia responden dengan kepuasan konsumen membeli sayuran organik di Kota Medan. Berdasarkan penelitian Devi dan Hartono (2015) di Kecamatan Tingkir, Jawa tengah, usia dinyatakan tidak berpengaruh nyata terhadap keputusan konsumen dalam membeli sayuran organik. Jadi, responden yang memiliki rentang usia produktif maupun dewasa memiliki kesadaran untuk menjaga kesehatan dengan mengonsumsi sayuran. Kalangan konsumen pada usia tersebut sudah memahami akan pentingnya sayuran sebagai salah satu bahan pangan yang harus mereka konsumsi untuk memelihara fungsi tubuh agar tetap sehat.

3.3 Hubungan Pendapatan Dengan Tingkat Kepuasan

Tabel 5

Tabulasi Silang Pendapatan dengan Tingkat Kepuasan

\begin{tabular}{|c|c|c|c|c|c|}
\hline \multirow{2}{*}{\multicolumn{2}{|c|}{$\begin{array}{l}\text { Frekuensi } \\
\text { Responden }\end{array}$}} & \multicolumn{3}{|c|}{ Tingkat Kepuasan } & \multirow[b]{2}{*}{ Total } \\
\hline & & $\begin{array}{l}\text { Tidak } \\
\text { Puas }\end{array}$ & Cukup & Puas & \\
\hline \multirow{9}{*}{$\begin{array}{l}\text { Pen- } \\
\text { dapat } \\
\text { an } \\
(\mathrm{Rp})\end{array}$} & $\begin{array}{c}0- \\
1.000 .000\end{array}$ & $\begin{array}{c}1 \\
(1 \%)\end{array}$ & $\begin{array}{c}3 \\
(4 \%)\end{array}$ & $\begin{array}{c}2 \\
(2 \%)\end{array}$ & $\begin{array}{c}6 \\
(7 \%)\end{array}$ \\
\hline & $\begin{array}{c}1.000 .001 \\
- \\
2.000 .000\end{array}$ & $\begin{array}{c}2 \\
(2 \%)\end{array}$ & $\begin{array}{c}1 \\
(1 \%)\end{array}$ & $\begin{array}{c}6 \\
(7 \%)\end{array}$ & $\begin{array}{c}9 \\
(10 \%)\end{array}$ \\
\hline & $\begin{array}{c}2.000 .001 \\
- \\
3.000 .000\end{array}$ & $\begin{array}{c}3 \\
(4 \%)\end{array}$ & $\begin{array}{c}10 \\
(11 \%)\end{array}$ & $\begin{array}{c}28 \\
(31 \%)\end{array}$ & $\begin{array}{c}41 \\
(46 \%)\end{array}$ \\
\hline & $\begin{array}{c}3.000 .001 \\
- \\
4.000 .000\end{array}$ & $\begin{array}{c}0 \\
(0 \%)\end{array}$ & $\begin{array}{c}8 \\
(9 \%)\end{array}$ & $\begin{array}{c}14 \\
(16 \%)\end{array}$ & $\begin{array}{c}22 \\
(25 \%)\end{array}$ \\
\hline & $\begin{array}{c}4.000 .001 \\
- \\
5.000 .000\end{array}$ & $\begin{array}{c}2 \\
(2 \%)\end{array}$ & $\begin{array}{c}0 \\
(0 \%)\end{array}$ & $\begin{array}{c}6 \\
(7 \%)\end{array}$ & $\begin{array}{c}8 \\
(9 \%)\end{array}$ \\
\hline & $\begin{array}{c}5.000 .001 \\
- \\
6.000 .000\end{array}$ & $\begin{array}{c}1 \\
(1 \%)\end{array}$ & $\begin{array}{c}0 \\
(0 \%)\end{array}$ & $\begin{array}{c}0 \\
(0 \%)\end{array}$ & $\begin{array}{c}1 \\
(1 \%)\end{array}$ \\
\hline & $\begin{array}{c}6.000 .001 \\
- \\
7.000 .000\end{array}$ & $\begin{array}{c}0 \\
(0 \%)\end{array}$ & $\begin{array}{c}0 \\
(0 \%)\end{array}$ & $\begin{array}{c}1 \\
(1 \%)\end{array}$ & $\begin{array}{c}1 \\
(1 \%)\end{array}$ \\
\hline & $\begin{array}{c}7.000 .001 \\
- \\
8.000 .000\end{array}$ & $\begin{array}{c}0 \\
(0 \%)\end{array}$ & $\begin{array}{c}1 \\
(1 \%)\end{array}$ & $\begin{array}{c}0 \\
(0 \%)\end{array}$ & $\begin{array}{c}1 \\
(1 \%)\end{array}$ \\
\hline & $\begin{array}{c}9.000 .001 \\
- \\
10.000 .00 \\
0\end{array}$ & $\begin{array}{c}0 \\
(0 \%)\end{array}$ & $\begin{array}{c}0 \\
(0 \%)\end{array}$ & $\begin{array}{c}1 \\
(1 \%)\end{array}$ & $\begin{array}{c}1 \\
(1 \%)\end{array}$ \\
\hline \multicolumn{2}{|c|}{ Total } & $\begin{array}{c}9 \\
(10 \%)\end{array}$ & $\begin{array}{c}23 \\
(26 \%)\end{array}$ & $\begin{array}{c}58 \\
(64 \%)\end{array}$ & $\begin{array}{c}90 \\
(100 \%)\end{array}$ \\
\hline
\end{tabular}

Sumber: Pengolahan data (2020)

Berdasarkan Tabel 5 dapat diketahui bahwa untuk responden dengan rentang pendapatan 2.000.001 - 3.000.000 rupiah paling banyak yang merasa puas membeli sayuran organik dengan jumlah 28 responden (31\%). Berdasarkan hasil uji chi-square diperoleh nilai probabilitas $0,065>0,05$ maka dapat disimpulkan bahwa Ho diterima yang 
artinya tidak terdapat hubungan yang signifikan antara pendapatan responden dengan kepuasan konsumen membeli sayuran organik di Kota Medan. Berdasarkan penelitian Devi dan Hartono (2015) di Kecamatan Tingkir, Jawa tengah, jumlah pendapatan keluarga dinyatakan berpengaruh nyata terhadap keputusan konsumen dalam membeli sayuran organik. Jadi, untuk keputusan konsumen dalam membeli sayuran organik sendiri dipengaruhi oleh jumlah pendapatan namun untuk kepuasan konsumen karena sudah membeli sayuran organik tidak ada hubungannya dengan pendapatan.

\subsection{Hubungan Pendidikan Dengan Tingkat Kepuasan}

\section{Tabel 6}

Tabulasi Silang Pendidikan dengan Tingkat Kepuasan

\begin{tabular}{|c|c|c|c|c|c|}
\hline \multirow{2}{*}{\multicolumn{2}{|c|}{$\begin{array}{l}\text { Frekuensi } \\
\text { Responden }\end{array}$}} & \multicolumn{3}{|c|}{ Tingkat Kepuasan } & \multirow[b]{2}{*}{ Total } \\
\hline & & $\begin{array}{l}\text { Tidak } \\
\text { Puas }\end{array}$ & Cukup & Puas & \\
\hline \multirow{6}{*}{$\begin{array}{c}\text { Pen- } \\
\text { didik } \\
\text { an }\end{array}$} & SMP & $\begin{array}{c}1 \\
(1 \%)\end{array}$ & $\begin{array}{c}0 \\
(0 \%)\end{array}$ & $\begin{array}{c}0 \\
(0 \%)\end{array}$ & $\begin{array}{c}1 \\
(1 \%)\end{array}$ \\
\hline & SMA & $\begin{array}{c}1 \\
(1 \%)\end{array}$ & $\begin{array}{c}1 \\
(1 \%)\end{array}$ & $\begin{array}{c}4 \\
(4 \%)\end{array}$ & $\begin{array}{c}6 \\
(6 \%)\end{array}$ \\
\hline & D3 & $\begin{array}{c}0 \\
(0 \%)\end{array}$ & $\begin{array}{c}3 \\
(3 \%)\end{array}$ & $\begin{array}{c}9 \\
(10 \%)\end{array}$ & $\begin{array}{c}12 \\
(13 \%)\end{array}$ \\
\hline & $\begin{array}{c}\text { D4 \& } \\
\text { S1 }\end{array}$ & $\begin{array}{c}5 \\
(6 \%)\end{array}$ & $\begin{array}{c}15 \\
(17 \%)\end{array}$ & $\begin{array}{c}42 \\
(47 \%)\end{array}$ & $\begin{array}{c}62 \\
(70 \%)\end{array}$ \\
\hline & $\mathrm{S} 2$ & $\begin{array}{c}1 \\
(1 \%)\end{array}$ & $\begin{array}{c}4 \\
(5 \%)\end{array}$ & $\begin{array}{c}2 \\
(2 \%)\end{array}$ & $\begin{array}{c}7 \\
(8 \%)\end{array}$ \\
\hline & S3 & $\begin{array}{c}1 \\
(1 \%)\end{array}$ & $\begin{array}{c}0 \\
(0 \%) \\
\end{array}$ & $\begin{array}{c}1 \\
(1 \%)\end{array}$ & $\begin{array}{c}2 \\
(2 \%)\end{array}$ \\
\hline \multicolumn{2}{|c|}{ Total } & $\begin{array}{c}9 \\
(10 \%)\end{array}$ & $\begin{array}{c}23 \\
(26 \%)\end{array}$ & $\begin{array}{c}58 \\
(64 \%)\end{array}$ & $\begin{array}{c}90 \\
(100 \%)\end{array}$ \\
\hline
\end{tabular}

Sumber: Pengolahan data (2020)

Berdasarkan Tabel 6 dapat diketahui bahwa untuk responden dengan pendidikan D4 dan S1 paling banyak yang merasa puas membeli sayuran organik dengan jumlah 42 responden (47\%). Berdasarkan hasil uji chisquare diperoleh nilai probabilitas 0,037< 0,05 maka dapat disimpulkan bahwa Ho ditolak yang artinya terdapat hubungan yang signifikan antara jenjang pendidikan responden dengan kepuasan konsumen membeli sayuran organik di Kota Medan. Berdasarkan penelitian Sari dkk. (2020), tingkat pendidikan formal dinyatakan berkorelasi secara nyata terhadap keputusan konsumen dalam membeli. Jadi, dapat disimpulkan bahwa tingkat pendidikan responden berpengaruh baik pada keputusan konsumen untuk membeli sayuran organik maupun kepuasan konsumen dalam membeli sayuran organik. Hal ini dapat terjadi karena semakin tinggi pendidikan seseorang maka semakin luasnya wawasan orang tersebut sehingga akan lebih berorientasi pada cara hidup yang sehat dengan mengonsumsi sayuran organik. Kesadaran konsumen akan manfaat terhadap kesehatan dari sayuran organik yang memunculkan loyalitas mereka dalam mengkonsumsi sayuran organik walaupun harganya lebih mahal dari sayuran nonorganik atau harganya naik sekalipun.

\subsection{Hubungan Jumlah Anggota Keluarga Yang Ditanggung Dengan Tingkat Kepuasan}

Tabel 7

Tabulasi Silang Jumlah Anggota

Keluarga yang Ditanggung dengan Tingkat Kepuasan

\begin{tabular}{|c|c|c|c|c|c|}
\hline \multirow{2}{*}{\multicolumn{2}{|c|}{$\begin{array}{l}\text { Frekuensi } \\
\text { Responden }\end{array}$}} & \multicolumn{3}{|c|}{ Tingkat Kepuasan } & \multirow[b]{2}{*}{ Total } \\
\hline & & $\begin{array}{l}\text { Tidak } \\
\text { Puas }\end{array}$ & Cukup & Puas & \\
\hline \multirow{10}{*}{$\begin{array}{c}\text { Jumlah } \\
\text { Anggo } \\
\text { ta } \\
\text { Keluar } \\
\text { ga } \\
\text { yang } \\
\text { Ditang } \\
\text { gung } \\
\text { (Ora- } \\
\text { ng) }\end{array}$} & & 1 & 7 & 13 & 21 \\
\hline & 1 & $(1 \%)$ & $(8 \%)$ & $(14 \%)$ & $(23 \%)$ \\
\hline & 2 & 1 & 4 & 21 & 27 \\
\hline & 2 & $(2 \%)$ & $(5 \%)$ & $(23 \%)$ & $(29 \%)$ \\
\hline & 3 & 3 & 6 & 11 & 20 \\
\hline & 3 & $(3 \%)$ & $(7 \%)$ & $(12 \%)$ & $(22 \%)$ \\
\hline & 4 & 1 & 3 & 8 & 12 \\
\hline & & $(1 \%)$ & $(3 \%)$ & $(9 \%)$ & $(13 \%)$ \\
\hline & 5 & 3 & 3 & 5 & 11 \\
\hline & $J$ & $(3 \%)$ & $(3 \%)$ & $(6 \%)$ & $(12 \%)$ \\
\hline \multirow{2}{*}{\multicolumn{2}{|c|}{ Total }} & 9 & 23 & 58 & 90 \\
\hline & & $(10 \%)$ & $(26 \%)$ & $(64 \%)$ & $(100 \%)$ \\
\hline
\end{tabular}

Sumber: Pengolahan data (2020) 
Berdasarkan Tabel 7 dapat diketahui bahwa untuk responden dengan jumlah anggota keluarga yang ditanggung sebanyak 2 orang paling banyak yang merasa puas membeli sayuran organik dengan jumlah 21 responden $(23 \%)$. Berdasarkan hasil uji chisquare diperoleh nilai probabilitas $0,335>$ 0,05 maka dapat disimpulkan bahwa Ho diterima yang artinya tidak terdapat hubungan yang signifikan antara jumlah anggota keluarga yang ditanggung responden dengan kepuasan konsumen membeli sayuran organik di Kota Medan. Berdasarkan penelitian Devi dan Hartono (2015) di Kecamatan Tingkir, Jawa Tengah, jumlah tanggungan keluarga dinyatakan tidak berpengaruh nyata terhadap keputusan konsumen dalam membeli sayuran organik. Jadi, dapat disimpulkan bahwa jumlah anggota keluarga yang ditanggung responden tidak berpengaruh baik pada keputusan konsumen untuk membeli sayuran organik maupun kepuasan konsumen dalam membeli sayuran organik.

\section{Kesimpulan}

Dari hasil penelitian yang telah dilakukan terhadap konsumen sayuran organik di kota Medan dengan ukuran sampel sebanyak 90 responden, dapat disimpulkan bahwa deskripsi karakteristik konsumen pada jenis kelamin didominasi oleh perempuan, usia didominasi pada 31 sampai 40 tahun, pendapatan didominasi pada 2.000.001 sampai 3.000.000 rupiah, lamanya tingkat pendidikan didominasi 16 tahun atau setara dengan S1 dan jumlah tanggungan keluarga didominasi oleh 2 orang dimana semua merasa puas saat membeli sayuran organik.

Kemudian variabel karakteristik konsumen yang berhubungan dengan tingkat kepuasan konsumen terhadap pembelian sayuran organik yaitu variabel pendidikan. Pengetahuan yang didapatkan konsumen selama menempuh pendidikan sangat terkait dengan tingkat kepuasan mereka dalam melakukan pembelian sayuran organik, hal tersebut terutama terkait dengan kesadaran konsumen akan manfaat terhadap kesehatan dari sayuran organik yang memunculkan loyalitas mereka dalam mengkonsumsi sayuran organik walaupun harganya lebih mahal dari sayuran nonorganik atau harganya naik sekalipun. Sayuran organik cenderung memiliki harga yang relatif lebih tinggi dibandingkan dengan sayuran anorganik. Hal tersebut disebabkan oleh proses produksi sayuran tanpa menggunakan bahan kimia yang digunakan untuk menghindari penyerangan hama dan penyakit serta baiknya kualitas sayuran organik oleh terbebasnya produk dari bahan kimia. Dengan tingkat pendidikan ini konsumen semakin banyak mendapatkan informasi-informasi mengenai gaya hidup sehat sehingga saat membeli dan mengonsumsi sayuran organik konsumen mendapatkan kepuasannya sendiri karena dirasa sangat bermanfaaat bagi kesehatannya.

\section{Daftar Pustaka}

Devi, S. R. M., \& Hartono, G. (2015). Faktor-faktor yang mempengaruhi keputusan konsumen dalam membeli sayuran organik. Agric, 27(1), 60-67.

Engel, J. F., Blackwell, R. D., \& Miniard, P. W. (1993). Perilaku Konsumen. Jilid I Alih Bahasa: FX Budyanto.

Junaidi, J. (2010). Prosedur Uji Chi-Square. Fakultas Ekonomi dan Bisnis Universitas Jambi.

Junaidi, J. (2014). Statistika Deskriptif dengan Microsoft Excel. Fakultas Ekonomi dan Bisnis Universitas Jambi.

Natawidjaja, R. S., Sulistiowaty, L., Kusno, K., Aryani, D., \& Rachmat, B. (2017). Analisis Preferensi, Kepuasan, dan Kesediaan Konsumen Membayar Beras Di Kota Bandung.

Pardian, P. (2017). Persepsi dan minat petani muda dalam budidaya sayuran Swiss Chard Organik. Dharmakarya, 6(3).

Purwati. (2017). Analisis Kepuasan dan Loyalitas Konsumen terhadap Sayuran Organik di Super Indo Yogyakarta. Skripsi. Program Studi 
Agribisnis, Fakultas Pertanian, Universitas Muhammadiyah Yogyakarta.

Rasmikayati, E., Hapsari, H., \& Saefudin, B. R. (2019). Peningkatan Pengetahuan dan Ketertarikan Remaja pada Hidroponik Berbasis Organik. Jurnal Pengabdian Kepada Masyarakat, 3(6), 147-151.

Rasmikayati, E., Pardian, P., Hapsari, H., Ikhsan, R. M., \& Saefudin, B. R. (2017). Kajian Sikap dan Perilaku Konsumen dalam Pembelian Kopi Serta Pendapatnya Terhadap Varian Produk Dan Potensi Kedainya. Mimbar Agribisnis: Jurnal Pemikiran Masyarakat Ilmiah Berwawasan Agribisnis, 3(2), 117-133.

Rasmikayati, E., Saefudin, B. R., Karyani, T., Kusno, K., \& Rizkiansyah, R. (2020). Analisis Faktor dan Tingkat Kepuasan Ditinjau dari Kualitas Produk dan Pelayanan pada Konsumen Sayuran Organik Di Lotte Mart Kota Bandung. Mimbar Agribisnis: Jurnal Pemikiran Masyarakat Ilmiah Berwawasan Agribisnis, 6(1), 351-364.

Saefudin, B. R., Deanier, A. N., \& Rasmikayati, E. (2020). Kajian Pembandingan Preferensi Konsumen pada Dua Kedai Kopi di Cibinong, Kabupaten Bogor. Agrovital: Jurnal Ilmu Pertanian, 5(1), 39-46.

Santoso, S., \& Tjiptono, F. (2001). Riset Pemasaran: konsep dan aplikasi dengan SPSS. PT. Elex Media Komputindo, Jakarta.

Sari, Y., Rasmikayati, E., Saefudin, B. R., Karyani, T., \& Wiyono, S. N. (2020, March). Willingness To Pay Konsumen Beras Organik Dan FaktorFaktor Yang Berkaitan Dengan Kesediaan Konsumen Untuk Membayar Lebih. In Forum Agribisnis (Vol. 10, No. 1, pp. 46-57).

Shanmugapriya, K. S., Gopal, S. M., \& Swaminathan, B. (2014). Consumer Preference of Organic Vegetables in the Coimbatore City of Tamil Nadu:
An Application of Logistic Regression Model. Trends in Biosciences, 7(23), 3886-3893.

Suleman, A., Prihandarini, R., \& Sudjais, Z. (2006). Menghantarkan Indonesia Menjadi Produsen Organik Terkemuka. Proceeding MAPORINA. Tangkulung, C. M., Pangemanan, L. R., \& Ngangi, C. R. (2015, August). Analisis Kepuasan Konsumen Terhadap Atribut Sayuran Organik di Hypermart Manado. In COCOS (Vol. 6, No. 14).

Utami, H. N., \& Chaeriyah, A. (2019). Customer Centricity: Kepuasan Konsumen Melalui Nilai Pelanggan Berdasarkan Value-In-Use Terhadap Kualitas Produk Sayur Organik (Studi kasus di Ujenk Mart Bandung, Jawa Barat). Agricore: Jurnal Agribisnis dan Sosial Ekonomi Pertanian Unpad, 3(1).

Utami, K., Rauf, A., \& Salmiah, S. (2019). Analisis Perilaku Konsumen dalam Pengambilan Keputusan Pembelian Sayur Organik di Kota Medan. Agrotekma: Jurnal Agroteknologi dan Ilmu Pertanian, 3(2), 75-84. 